Abstracta Iranica Abstracta Iranica

Revue bibliographique pour le domaine irano-aryen

Volume 29 | 2008

Comptes rendus des publications de 2006

\title{
Hidden Iran: Paradox and Power in the Islamic republic. Times Book, 2006, 272 p.
}

\section{Anicée Van Engeland}

\section{(2) OpenEdition}

10 Journals

\section{Édition électronique}

URL : http://journals.openedition.org/abstractairanica/32682

DOI : 10.4000/abstractairanica.32682

ISSN : 1961-960X

Éditeur :

CNRS (UMR 7528 Mondes iraniens et indiens), Éditions de l'IFRI

\section{Édition imprimée}

Date de publication : 15 mai 2008

ISSN : 0240-8910

\section{Référence électronique}

Anicée Van Engeland, «Hidden Iran: Paradox and Power in the Islamic republic. Times Book, 2006, 272 p. », Abstracta Iranica [En ligne], Volume 29 | 2008, document 386, mis en ligne le 15 septembre 2008, consulté le 26 septembre 2020. URL : http://journals.openedition.org/abstractairanica/32682 ; DOI : https://doi.org/10.4000/abstractairanica.32682

Ce document a été généré automatiquement le 26 septembre 2020.

Tous droits réservés 


\title{
Hidden Iran: Paradox and Power in the Islamic republic. Times Book, 2006, $272 \mathrm{p}$.
}

\author{
Anicée Van Engeland
}

1 L'A. critique l'approche américaine envers l'Iran, qu'il considère comme manquant de nuances, et ce depuis 1979. Les sanctions ont été inefficaces et l'isolation du pays n'a pas abouti aux résultats attendus. Le problème, selon Ray Takeyh, est que la politique iranienne a été approchée comme étant un ensemble monolithique alors que la réalité est fort différente. Il demande au gouvernement américain d'abandonner sa " chimère » de renversement du régime pour s'adapter. Il ajoute que l'Iran ne cessera pas d'essayer d'obtenir l'arme nucléaire. Enfin, il encourage l'élaboration d'une collaboration sélective entre l'Iran et les États-Unis sur des sujets comme l'Irak. Il insiste donc sur l'établissement d'un dialogue permanent.

\section{INDEX}

Thèmes : 13.1. Iran

\section{AUTEURS}

\section{ANICÉE VAN ENGELAND}

European University Institute - Florence 